\title{
マイクロバブルの基礎と最近の進展
}

\section{Fundamentals and Recent Advances on Microbubbles}

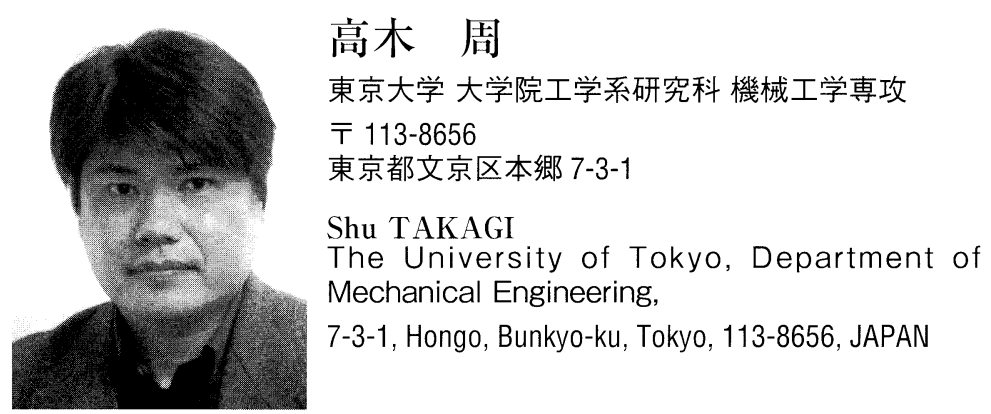

論文要旨：水中に存在する微細な気泡は, その比表面の大きさおよび液中での停留時間が長いことから気 液反応の促進を目的とした化学反応器や水処理の曝気槽などで有効に利用されている。また，医療応用と関 連した分野では，直径 5 ミクロン以下の微細なマイクロバブルは，静脈への注射を通して超音波血管造影剤 としてすでに利用されており，最近では，このマイクロバブルに改良を加え，血流を利用したドラッグデリ バリー担体としての利用も考えられている。本稿では, マイクロバブルに関する研究について最近の研究動 向を紹介した後, 気泡サイズや発生数などの制御性に優れ, 将来の医療応用も期待できるマイクロチャネル を利用したマイクロバブル生成法について紹介する。

\begin{abstract}
Tiny bubbles in water have large specific area and long residence time in a tank. Because of these characteristics, they are used to enhance the mass transfer between gas and liquid phase in chemical reactors, aeration tanks for water purification systems etc. Also, there are a lot of expectations in the medical filed. Microbubbles, whose diameter is less than $5 \mu \mathrm{m}$, have been already used as contrast agents of ultrasound diagnosis through the injection into veins. These microbubbles are expected to be further utilized as drug delivery agents through the development of special device to control the microbubble functions. In this paper, the recent advances on these microbubble studies are explained and the microbubble generator using microchannel, which has good controllability on bubble size and numbers, are briefly introduced.
\end{abstract}

Key words: medical application, contrast agent, microbubble generation, micro fluidics, water purification, cavitation

\section{1 はじめに}

気相・液相・固相など異なる相が複雑に干渉し合いな がら流動構造が決定される流れを混相流と呼ぶ。混相流 では，層流の状態に扮いてもさまざまな時空間スケール の構造が流机の中に存在し, ミクロ・メゾ・マクロといっ た異なるスケール間の干渉が流動構造を決める多重ス ケール構造をなす。また, 一口に混相流と呼んでも, さ まざまなタイプの流れが存在し，それぞれの流れで多重 スケール構造も異なるものとなる。中でも, 液体中に多 数の気泡や液滴・粒子などの分散相を含む分散系混相流 では, 多重スケール性がとくに重要となる。分散系混相

連絡者：高木 周

E-mail : takagi@mech.tu-tokyo.ac.jp
流は, 流体機械を始め, 化学反応器, 熱交換器, エンジ ンの燃料噴射部, 水处理のための曝気槽など, 工学上重 要となるさまざまな装置で見受けられる。とくに最近で は, マイクロ・ナノテクノロジーの進展に伴い, 大きさ がサブミリ以下のマイクロ分散相やナノ分散相に関連す る応用技術が増え，そ机らマイクロ分散相に対する基礎 知識が重要となってきている。とくに最近では, マイク ロ・ナノテクノロジーの進展に伴い, 大きさがサブミリ 以下のマイクロ分散相やナノ分散相に関連する事柄が増 え, それらマイクロ分散相に対する基礎知識が重要と なってきている。

本稿では, これらさまざまな利用が期待されているマ イクロ・ナノ分散相のうち, とくに微細な気泡に関連す る話題について, 基礎的な事項を踏まえて, 最新の研究 
動向を説明する。

\section{2 最新の研究動向}

\section{$2 \cdot 1$ 医療分野でのマイクロバブル}

直径数ミクロン程度のマイクロバブルは，医療応用方 面で大きな期待をされており，すでに医療現場で活用さ れている。血管内に直径 5 ミクロン以下のマイクロバブ ルを注入することにより，血管を見るための造影剤とし て使用することができる。体外からあてられた超音波に より，血管内にある気泡が血管中で振動して大きく超音 波を反射する。気泡から返ってくるこの反射音を処理す ることにより，毛細血管の位置を知ることができる。と ころで，がん細胞の周りには毛細血管が非常に発達し, またその様相も通常のものと大きく異なることが知られ ている。そのため, がん細胞の近傍ではマイクロバブル が集積しやすく，反射音が正常な細胞とは異なるため, がん細胞の部位を検出することも可能となる。さらに, 血管造影用マイクロバブルを含んだ血管に超音波を照射 することにより，気泡の振動を介して，音響エネルギー を熱エネルギーに変換し，がん細胞の焼灼を行うことも 考えられている。Fig. 1 は体組織を模擬したポリアクリ ルアミドゲルに対して，集束超音波を照射し，焦点付近 の温度上昇を感温液晶で可視化した結果である。右側の 結果は，焦点付近に超音波血管造影マイクロバブルの一 つである Levovist を注入した場合のもので，左側の注 入していない場合と比較し，温度上昇している領域が時 間とともに急激に増大している様子がわかる。

このように，体外から与えられる超音波による音響エ

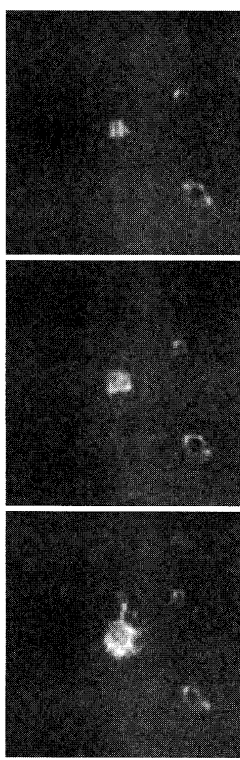

No bubbles

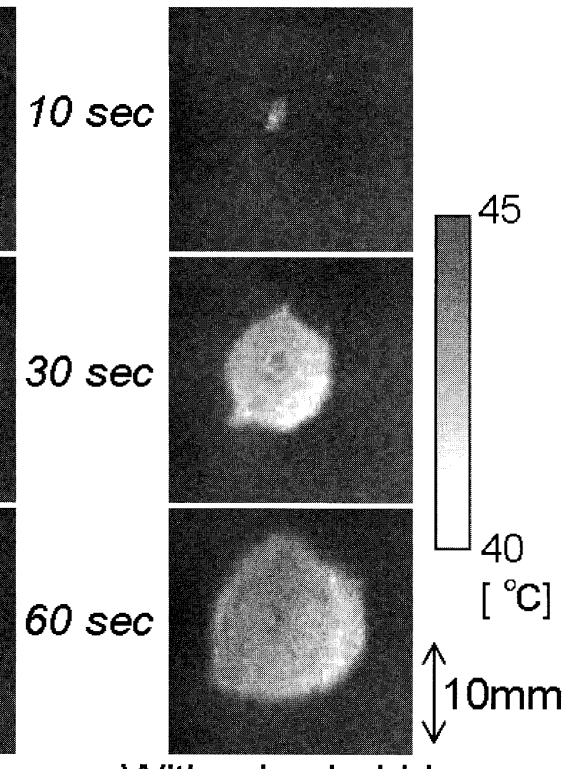

With microbubbles
Fig. 1 Visualization of Temperature rise Using Liquid Crystal Thermometry.

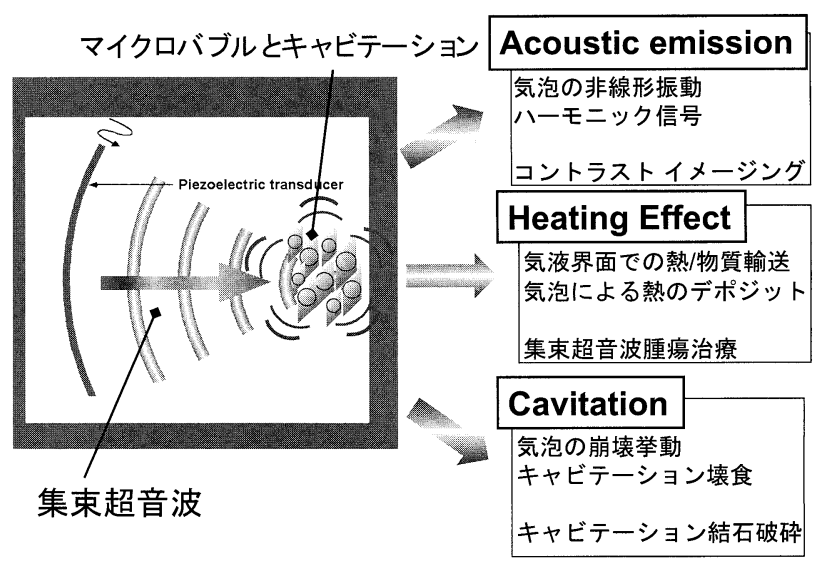

Fig. 2 Medical Applications of Microbubbles.

ネルギーをマイクロバブルやキャビテーション気泡を介 して熱エネルギーや力学的エネルギーに変換することに より，悪性腫瘍の焼灼や，結石の破砕を行い，人体を切 開することなく非侵襲的な治療を行う技術の開発が大き く期待されている（Fig. 2 参照）。また，最近では，血 管造影用マイクロバブルに薬剤などを化学修飾しドラッ グデリバリー担体として利用することも検討され始めて いる。

\section{$2 \cdot 2$ 水処理分野でのマイクロバブル}

環境問題と関連して，水処理技術へのマイクロバブル の適用などが大きな注目を集めている。水質浄化槽や化 学反応器などにおいてとくに重要となる微小上昇気泡群 を含む流れにおいては，Fig. 3 に示すように，個々の気 泡の表面に扮ける界面活性剤の存在など分子スケールの ミクロな現象から，流れ場全体のマクロな構造に到るま で，ミクロ・メゾ・マクロのさまざまなスケールの現象 が複雑に干渉し合いながら流動構造が決定されている。 例えば，微量の界面活性剤を含む水では，直径 $1 \mathrm{~mm}$ 以 下の小さな気泡に働く抵抗は, 球形気泡の值よりも剛体 球の值にほぼ等しくなることが知られている。また，界 面活性剤の存在する水中では気泡同士の合体が非常に起 こりづらくなることも知られている。このように，微量 の界面活性剤が上昇速度を大幅に減少させたり，気泡同 士の合体を妨げたりすることにより，気泡流全体の挙動 が大きく変わってくる1)。すなわち，これらの流れにお いては，個々の分散相表面における界面活性剤や電解質 の存在など分子スケールのミクロな現象が，個々の気泡 の挙動を大きく変化させ, 結果として, 水質浄化システ ムにおいて現れる気泡プルームのようなマクロな流動構 造にも大きな影響を与え，浄化性能を大きく変化させる ことになる。

微量の界面活性剤の存在により上昇速度が著しく低下 するメカニズムについては，気泡の上昇運動に伴い，気 


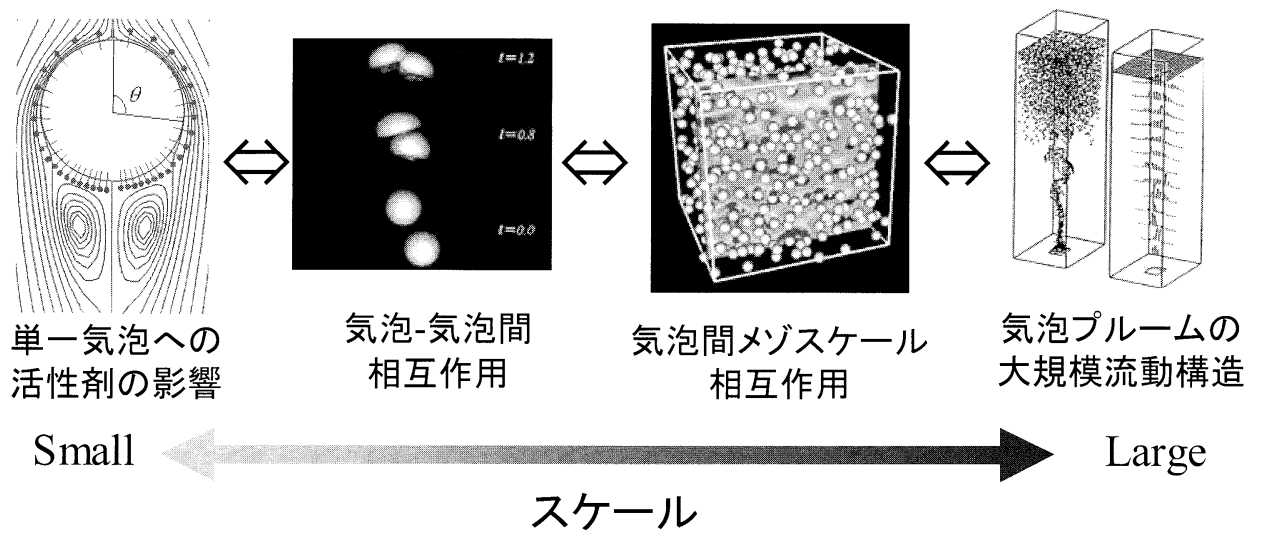

Fig. 3 Multiscale Strucure of Bubbly Flows.

泡表面に沿って界面活性剂の濃度分布が存在し，その濃 度に依存して表面張力が変化することによりもたらされ るマランゴニ効果で説明がつき, 実際, マランゴニ効果 を取り入れた数值計算の結果は実験結果と良好な一致を 示す ${ }^{2)}$ 。一方，表面活性剂が気泡同士の合体を妨げるメ カニズムについては未知な点が多い。一般に，連続体レ ベルのスケールで起こる現象としては, 気泡同士が接近 した際の 2 つの気液界面の間の液膜は，界面活性剂の存 在する場合には，マランゴニ効果により界面での速度す ベりがない状態に近くなり，そのため，接近する二つの 界面間には潤滑理論で説明のつく反発力が生じる。この 反発力により気泡同士の合体が妨げられるとする ${ }^{3)}$ 。一 方，さらに界面が近づいて分子レベルの現象になると気 泡表面に吸着した界面活性剂による静電気的な力によ り，非常に接近した界面同士に反発力が働き合体が阻害 されると考えられている。この領域になると実験的な観 測も難しく，今後の詳細な分子シミュレーションによる 予測に期待するところである。

ところで，マイクロバブルは，通常の $\mathrm{mm}$ サイズ以 上の気泡と比較し，上昇速度が非常に小さくなる。気液 界面に㧍けるガス交換の観点からは，比表面の増加その ものよりも，この上昇速度の低下による水中での停留時 間の増加が非常に重要な因子となる。Gong ら ${ }^{4)}$ は，曝 気槽内気泡プルームの数值計算を行い，気泡の噴出し位 置の違いによる影響を数值計算により調べている。この 計算では，従来サイズの気泡の場合には，タンク底面中 央から気泡を噴出しても, タンク底面全体から噴出して も，気泡自身の水中の停留時間は大きく変化せず，した がって気泡から液中へのガスの溶解効率も大きく変化し ないのに対し，マイクロバブル噴出しの場合には，大き く異なってくることが示されている。すなわち, タンク 底面中央からマイクロバブルを噴出した場合には，誘起 される循環流れが気泡自身の周囲流体に対する相対速度
に対してはるかに大きな值となるため，噴出された気泡 はその流れに乗り，短時間で水面までたどりついてしま うことになる。これに対し，タンク底面全体からの噴出 した場合は，十分長い停留時間を確保することができ， ガスの溶解効率が著しく改善することになる。これらの 知見は, 従来の装置に対して気泡噴出し部のみをマイク ロバブル発生装置に変更しただけでは，マイクロバブル の特性を十分に活かしきれないことを示しており，実際 にマイクロバブルを利用する場合には，従来の装置に対 する変更点として注意が必要である。

\section{$2 \cdot 3$ バブル技術の実用化に向けて}

上述の通り，マイクロバブルの実用例として，その有 効性が示されており，今なお，多くの研究者の研究対象 となっているのは，水処理関連の技術である。一般にマ イクロバブルによる曝気槽を用いた水処理の場合には, マイクロバブルを用いることによる気液界面の接触面積 の増加および液中における停留時間の大幅な増加による 物質輸送特性の向上によるメリットが期待できる。一方, マイクロバブル発生装置には通常の気泡発生装置よりも 大きな動力が必要となる。そのため, マイクロバブルを 用いた際の効率の向上分とマイクロバブルを生成するた めに必要な動力の増加分との差し引きで省エネとしての 議論がなされる。さらに目詰まりの問題などメンテナン スコストまで考慮した際には，常に劇的なメリットが主 張できるわけではないというのが著者の認識である。た だし，装置の小型化の観点からは，マイクロバブルを利 用することのメリットは明らかである。すなわち，水処 理システム全体の小型化を含めて，マイクロバブルを用 いた省スペースシステムの構築とそれにともない空いた スペースの有効活用まで含めた議論をすれば，そのメ リットがより顕著になると考える。

ところで，マイクロバブルではないが，気泡噴出しに よる動力増加の分を考慮しても，全体として省エネが達 
成され，実際の大型船舶に挹いて商品として最近害用化 されたものとして以下の記事がある。

URL : http://www.mhi.co.jp/nsmw/news/story/ 20100329A.html

筆者らは, 文部科学省解放的融合研究「乱流制御によ る新機能熱流体システムの創出」(平成 $12 \sim 16$ 年) に 拝いて，マイクロバブル噴出しによる船舶の推進抵抗低 減に関わるプロジェクトに参加していた経緯もありここ の話を聞いて感銘を受けた。上記の船舶の開発には関 わっていないが，文科省の開放融合プロジェクトに関 わっていた際には，船底への気泡噴出しに必要な動力に よるコストの増加および船舶推進プロペラ部における気 泡巻き込みに伴う，推進力の低下などの問題があり，気 泡噴出しに伴う推進抵抗低減のメリットについて商品化 にいたるレベルでは十分に示されてはいない状況であっ た。これに対し，船底が広く浅いところにある荷物運搬 船を対象にし，かつ推進プロペラへの気泡吹き込みよる 推進力低下の問題を避けるための工夫を施し, 気泡噴出 し方法を十分検討し, 結果として大型の船舶へ適用され 実用化へと結びついたのは，気泡噴出しによるメリット だけではなく，システム全体の設計をきちんと達成でき たためと考える。マイクロバブルに関する技術が，広く 普及するためにはやはりこのような視点による装置全体 の設計が重要なポイントである。

\section{$2 \cdot 4$ ナノバブルに関して}

近年ナノスケールの気泡（ナノバブル）の存在が基礎 研究の分野で話題になっている。超撥水性物質の表面に

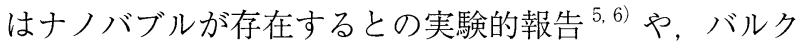
の水中においても超音波照射によりナノバブルが生成さ れる ${ }^{7)}$ などの報告がある。一般に小さな気泡は表面張 力の影響が大きくなり，きれいな水を考えた場合には， 単純な見積もりだとナノバブルの内部の圧力は 100 気圧 を超えうる。このような状況では気泡中のガスは, 周囲 液体に容易に溶解し, 気泡は水中に安定して存在するこ とはできないと考えられる。理論によると，ナノバブル の生存時間は, 半径 10 ナノメートルの気泡では 1 マイ クロ秒, 半径 100 ナノでは 100 マイクロ秒程度と見積も られている。ところが実際に観測されているナノバブル は，それよりはるかに長い寿命を持ち，水中に存在する 微量の界面活性剂や超撥水性物質の表面の構造が気泡の 安定化に大きく寄与していると考えられるが未知な点が 多い。通常の光学顕微鏡では観測できない領域となるた め, 分子シミュレーションと実験結果の相補的な利用に より現象の本質に迫ることが期待される。
3

\section{開発}

\section{$3 \cdot 1$ 背景}

すでに述べた通り，超音波血管造影剤として用いられ るマイクロバブルにさまざまな機能を付加し， ドラッグ デリバリーシステムに対しても利用しょうとする試みが ある。このような医療応用に対するマイクロバブル生成 技術の開発は, 水処理のときに重視される, 気泡生成に かかるコストや装置のメンテナンス性よりも，コストが 多少かかっても単分散の気泡径を持ち, 気泡表面への化 学修飾性に優れた制御性の良い手法で作成できることが 重要となる。ここでは, これらを背景に, 将来の高機能 マイクロバブル生成に向けて, マイクロチャネルを利用 した微細気泡生成技術について紹介する。

マイクロバブル生成手法の一つとして, $\mathrm{T}$ 字型のマイ クロチャネルを用いた手法が広く研究されており, 気泡 径のスケーリング則等についての知見が得られている ${ }^{8,9)}$ 。 $\mathrm{T}$ 字型マイクロチャネルを用いた生成方法は, 気泡径の 制御性 - 均一性, 液相 - 気相種類や気泡表面修飾の選択 性といった点で優れている一方，毛細血管を通過するの に必要となる数 $\mu \mathrm{m}$ の微小な気泡径を実現する技術はい まだ確立されていない。

ここでは絞り部を持つ T字型マイクロチャネルに平 均流速約 $1 \mathrm{~m} / \mathrm{s}$ で液相を流すことで小径気泡を生成す る手法について紹介する。 van Steijn ら ${ }^{10)}$ は $800 \mu \mathrm{m}$ 角 の T字合流部で気泡が生成する過程において, $\mu$-PIV (micron-resolution Particle Image Velocimetry) ${ }^{11}$ によっ て流れ場を計測することに成功している。しかし従来の マイクロ粒子画像計測法では, 最大でも数 $\mathrm{mm} / \mathrm{s}$ の流 速までしか計測できない。そこで著者らの研究グループ では従来困難であった数 $\mathrm{m} / \mathrm{s}$ の流速場計測を実現する システムを構築し, 高流速下での気泡生成過程に扔ける 気液界面の変化と液相流れ場の様子を調べることで, 気 泡生成時の動力学を解析することで，より微細な気泡を 生成するために重要となる知見を得ることを目的として 研究を進めている。以下, 実験方法と現時点で得られて いる結果について紹介する。

\section{$3 \cdot 2$ 実験方法}

実験に用いたチャネルの形状の模式図を Fig. 4 に, T 字部での流路寸法を Table 1 に示す。 $D_{h}$ は水力等価直径 を表す。実験には 3 種類の異なる寸法のチャネルを用い た。それぞれをチャネル A， B , C , D と呼ぶことにする。 液相と気相が中央の $\mathrm{T}$ 字部で合流し, 気泡が生成され る仕組みとなっている。液相の圧力損失を抑えるために, 合流部前後では液相流路幅が広く設計されている。液相 


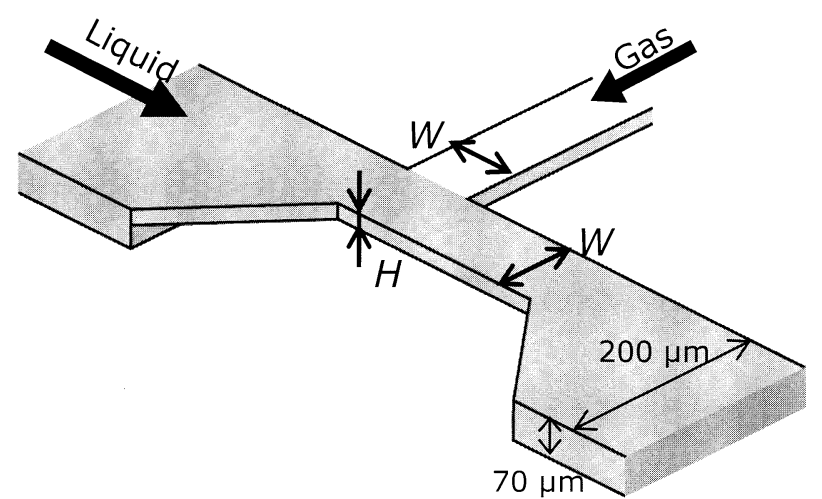

Fig. 4 Shape of the T-junction.

Table 1 Channel Size of T-junction

\begin{tabular}{l|c|c|c}
\hline & $W[\mu \mathrm{m}]$ & $H[\mu \mathrm{m}]$ & $D_{h}[\mu \mathrm{m}]$ \\
\hline Channel A & 110 & 20 & 34 \\
Channel B & 50 & 11 & 18 \\
Channel C & 50 & 7 & 12 \\
Channel D & 24 & 2 & 4 \\
\hline
\end{tabular}

Table 2 Liquid Properties

\begin{tabular}{l|c|c|c}
\hline & $\rho\left[\mathrm{g} / \mathrm{cm}^{3}\right]$ & $\sigma[\mathrm{mN} / \mathrm{m}]$ & $\mu[\mathrm{mPa} / \mathrm{s}]$ \\
\hline Pure water & 0.998 & 72.7 & 1.00 \\
99.5\% Ethanol & 0.789 & 22.4 & 1.20 \\
Silicon oil 0.65cs & 0.760 & 15.9 & 0.494 \\
Silicon oil 2cs & 0.837 & 18.3 & 2.29 \\
\hline
\end{tabular}

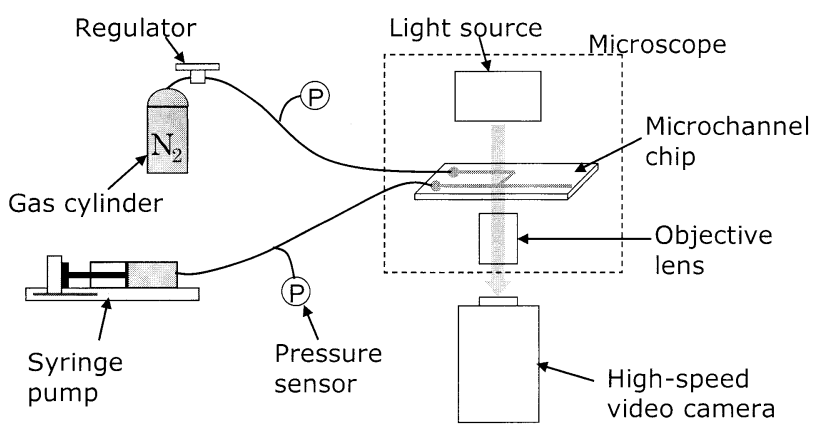

Fig. 5 A Schematic Illustration for the Experimental Apparatus.

流速を $0.1 \sim 3.5 \mathrm{~m} / \mathrm{s}$ で, 気相圧を $20 \sim 230 \mathrm{kPa}$ で変化 させ，液相の物性值や流路寸法が生成気泡系に与える影 響を調べた。ここで液相流速とは T 字部での平均流速 を表す。さまざまな条件下に打ける気泡挙動を解析する ため液相には純水，エタノール抢よび 2 種類のシリコー ンオイルを用い，シリンジポンプ (Eicon, 81520) によ る流量制御で駆動した。各液相種の物性值を Table 2 に 示す。また，Fig. 5 に実験装置の概略を示す。気相には 窒素を用い, レギュレータによる压力制御で駆動して, マイクロチャネル内の T字部で液相と合流させて気泡

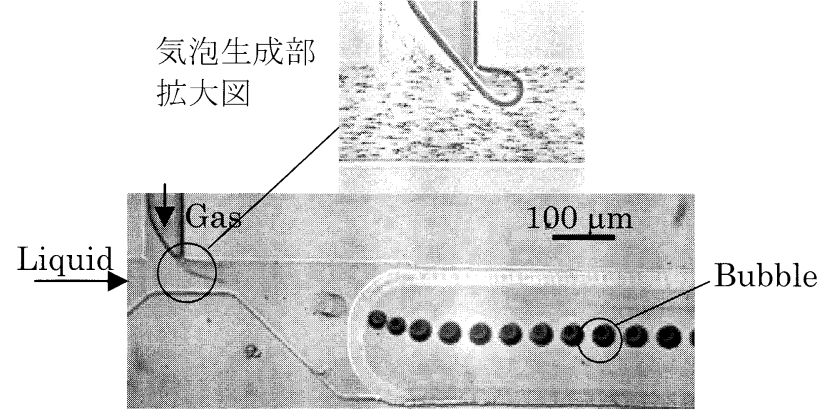

Fig. 6 Snapshots of Microbubble Generation.

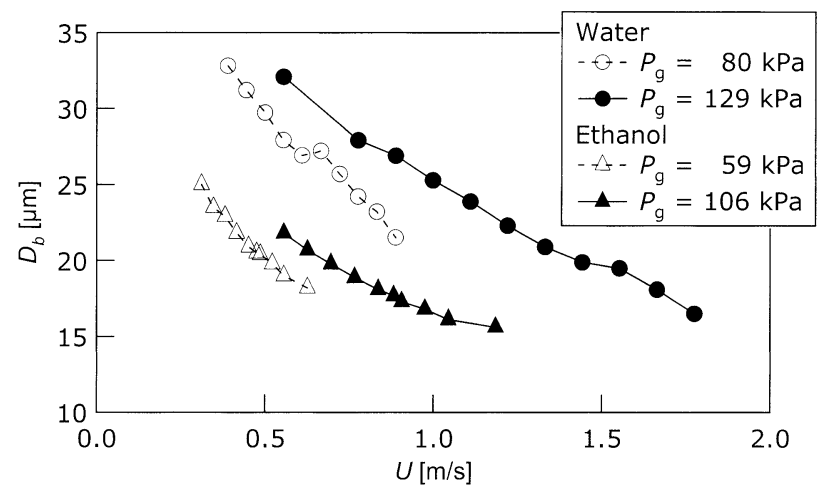

Fig. 7 Liquid Velocity and Bubble Diameter (Channel C).

を生成した。その様子を高速度カメラ (Redlake, MotionPro 10000）を用いて撮影した。気泡生成は $100 \mu \mathrm{s}$ 程度という極めて短い時間スケールで起きるた め, 撮影は $800 \mathrm{fps}$ のフレームレートで行った。

\section{$3 \cdot 3$ 液相流速と気泡径}

気泡が生成する様子をFig. 6 に, チャネル A での液 相流速と気泡径の関係を Fig. 7 に示す。液相流速は T 字部での平均流速を表す。いずれの液相でも流速を上げ ることでより小さい気泡が生成されることが確認され た。これは Garstecki ら ${ }^{8)}$ の結果とも定性的に一致する。 また，同条件においては純水に比べてエタノールの場合 の方が気泡径は小さくなった。これは純水とエ夕ノール の表面張力の違いに依るものと考元られ，表面張力の小 さいエタノールの系の方が, 気泡が分裂しやすいことに 対応している。表面張力の詳細な効果については更なる 考察が必要である。液相流速を上げていくと, ある点で 気相が $\mathrm{T}$ 字部から押し戻されて気泡が生成されなくな る流速が存在するが, この限界の流速は気相圧が高いほ ど大きくなった。これ以降，便宜的に気泡が生成される 最大の液相流速を限界流速, 打よびその状態を気泡生成 限界と呼ぶ。本実験では, 生成限界において最小で体積 等価直径 $15 \mu \mathrm{m}$ 程度の気泡生成に成功している。なお, 気泡生成限界での気泡径や, 気相圧と限界流速の関係に ついて非常に興味梁い関係が成り立つ。以下，その説明 


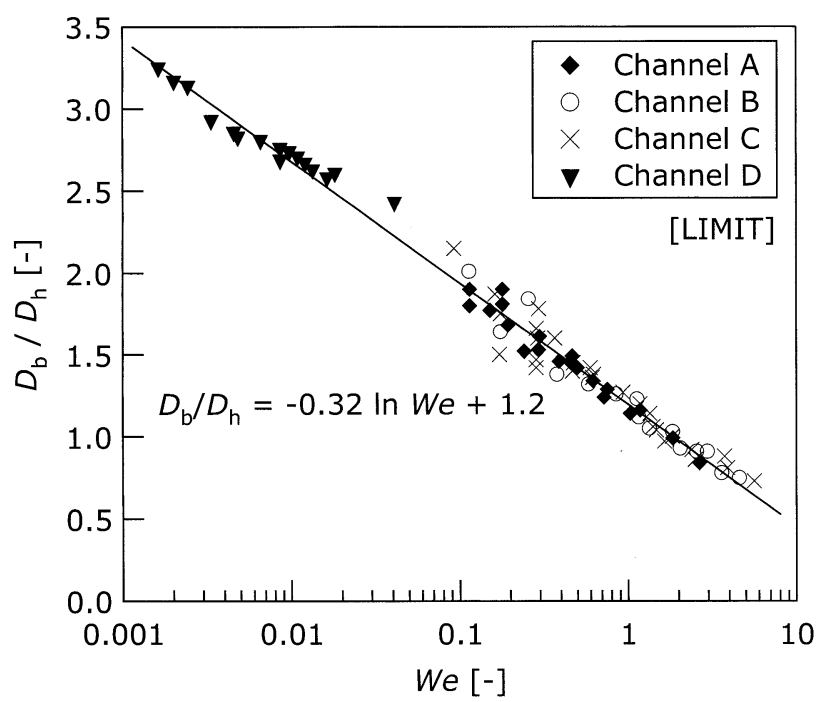

Fig. 8 Relation between $W e$ and $D_{b} / D_{h}$.

を行う。

\section{$3 \cdot 4$ 気泡生成限界での気泡生成}

Table 2 のすべての液相種を用いて, 気相圧力, 液相 流速を変化させて気泡生成限界での気泡径を調べた。無 次元数による比較を行うために，以下で定義される Weber 数により整理した。

$$
W e=\rho U^{2} D_{h} / \sigma
$$

横軸にWeber 数を取り, 縦軸に気泡径 $D_{b}$ を流路の 水力等価直径で規格化したものを取って整理したグラフ をFig. 8 に示す。本実験条件下では液相種，チャネルの 寸法によらずおよそ一定の関係が見られ，

$$
D_{b} / D_{h}=-0.32 \ln W e+1.2
$$

という関係式で近似できることが確認された。グラフか らもわかる通り, We 数自体の值は小さな值であるが, 限界流速の条件で整理すると粘性の効果が現れず，表面 張力で整理できるのは非常に興味深い結果である。

\section{4 おわりに}

本稿では, マイクロバブルに関する最近の研究動向と その基礎になっている知識について説明した。また，気 泡径や生成個数の制御性に優れたマイクロチャネルを用 いたマイクロバブル生成手法について紹介した。マイク ロバブルに関する研究がとくに活発になり10 年程度と なるが,この分野が今後も更なる発展を遂げるためには， これまでの知見を活かしかつ恒久的なものとして技術が 残るような新たな装置 (システム) の創出が期待される。

\section{謝 辞}

本稿で紹介した研究内容は, 東京大学工学系研究科機 械工学専攻・流体工学研究室にて行われた研究の成果に 基づいている。研究室のメンバーに記して感謝の意を表 する。

\section{文献}

1) Takagi, S. and Matsumoto, Y., Annu. Rev. Fluid Mech. 43，(2010），掲載予定.

2）高木周他，日本機械学会論文集，69-686, pp.2192-2199 (2003)

3) Dai, B., Leal, L. G., Phys. Fluids, 20, 040802 (2008).

4) Gong, X., Takagi, S. \& Matsumoto, Y., Int. J. Multiphase Flows, 35, pp.155-162 (2009).

5) Ishida, N., et al., Langmuir 16, 6377 (2000).

6) Tyrrell, J. W. G. \& Attard, P., Phys. Rev. Let., 87. 176104 (2001).

7) 後藤瑞希他, 第 40 回伝熱シンポジウム講演論文集, A215, CD-ROM (2003).

8) Garstecki, P., et al., Lab. Chip., 6, 437-446 (2006).

9) Zhang, Y., et al., Nanoscale Microscale Thermophys. Eng., 13, 228-242 (2009).

10) van Steijn, V., et al., Chem. Eng. Sci., 62, pp.7505-7514 (2007).

11) Santiago, J. G., et al., Exp. Fluids, 25, 316-319 (1998). 